\title{
A Probe into the Renaissance of Confucianism in Song Dynasty and Women's Politeness
}

Jing He, Mengjia Gu, Yuwen Zhang

Jing He, Sichuan University Jinjiang College, No.1 Jinjiang Avenue, Pengshan District, Meishan City, Sichuan Province.

Email: 2930518682@qq.com, Postcode: 620860.

Mengjia Gu, Peking University, Foreign language building, Peking University, 5 Yiheyuan Road, Haidian District, Beijing.

Email: 2325905134@qq.com, Postcode: 100871.

Yuwen Zhang, Weihai Campus of Shandong Jiaotong University, 1508 Hexing Road, chucun Town, Huancui District, Weihai City, Shandong Province.

Email: 1668379794@qq.com, Postcode: 264200

Abstract: The revival of Confucianism in the Song Dynasty is of great significance to the development of the Confucian school.Based on the development of Confucianism and systematic research, it can be found that the Song Dynasty is an important period of Confucianism revival, and also a period that cannot be ignored in the study of Confucianism. In general, the Confucian renaissance in the Song Dynasty was caused by many reasons, and under the background of the Confucian renaissance, Taoism and Buddhism have developed significantly, which has caused a large number of female rituals in the society.Analysing and studying the Confucian renaissance in Song Dynasty and the phenomenon of women's rites and buddhas are significant for understanding the cultural environment of Song Dynasty and understanding social life in Song Dynasty.The article makes a concrete analysis of the Confucian renaissance in Song Dynasty and the phenomenon of women's ritual Buddha, aiming to clarify the specific reasons of Confucian renaissance and the cause and influence of women's ritual Buddha.

Keywords: Song Dynasty; Confucianism revival; pray at the buddha phenomenon

Confucian culture is an important part of my country's traditional culture and has experienced thousands of years of development.Throughout the long process of history, the development of Confucian culture has gone through the pre-Qin and Han Dynasties, and it has become one of the main cultures in society. Confucianism has also become one of the most important ideas that affect Chinese society.Since the Tang Dynasty, the five nomadic tribes bane chinese have caused the original social order to fall apart, and the Confucian cultural system that emphasizes etiquette, advocating virtue, and seeking benevolence has been hit hard.After the Five Dynasties, the Northern Song Dynasty unified the Central Plains and a new social order was established.Under the new social order, the implementation of the rulers' policies and the prosperity of education led to the renaissance of Confucianism again, and achieved remarkable development results.Analyze and study the social impact of Confucianism revival and the promotion of social culture, etc. This has outstanding practical value in analyzing and understanding the Song Dynasty Confucianism revival.

\section{An Analysis of the Revival of Confucianism in the Song Dynasty}

After the chaotic world of fivenomadic tribes bane chinese, the Northern Song Dynasty completed the reunification

Copyright (C) 2020 Jing He et al.

doi: 10.18282/le.v9i5.1203

This is an open-access article distributed under the terms of the Creative Commons Attribution Non-Commercial License

(http://creativecommons.org/licenses/by-nc/4.0/), which permits unrestricted non-commercial use, distribution, and reproduction in any medium, provided the original work is properly cited. 
of the Central Plains region, and the development of the Central Plains entered a stable period, with significant progress in society, politics, economy, and culture.As an important representative of culture, Confucianism experienced the withering of the late Tang Dynasty and the Five Dynasties and regained prosperity in the Northern Song Dynasty. It can be said that Confucianism achieved a revival in the Northern Song Dynasty.Analysis of the Confucian renaissance during the Northern Song Dynasty has significant value in understanding the current cultural situation of the Northern Song Dynasty.

\subsection{Reasons for revival}

In the Song Dynasty, the reason why Confucianism has achieved a revival is inseparable from several reasons. The following is a specific analysis.

The first is the development of Confucianism itself ${ }^{[1]}$. From the perspective of the social environment, during the Wei, Jin, and Northern and Southern Dynasties, Buddhism prevailed in my country, and part of Buddhism's ideas were integrated into my country's mainstream ideas.In addition, the development of Taoism at this stage is also remarkable, and Taoist ideas and thoughts have also had a significant impact in society. When Buddhism and Taoism developed into the Sui and Tang Dynasties, their integration with Confucianism became more and more obvious. At this time, in order to fight against Buddhism and Taoism, Confucianism actively absorbed the ideas in Buddhism and Taoism for their own use, thus forming a new Confucianism system, which is a far-reaching Confucianism.In other words, the development of Confucianism itself provided stable support for the renaissance of Confucianism in the Song Dynasty.

Secondly, the cultural and ideological atmosphere of the Song Dynasty is relatively loose ${ }^{[2]}$.After the founding of the Northern Song Dynasty, Emperor Taizu of Song Zhao Kuangyin learned the painful lessons of the separatist rule of the feudal towns in the late Tang Dynasty and the Five Dynasties and the rule of the generals, and actively implemented the policy of suppressing the martial arts.As the so-called the subordinates will follow the example set by their superiors, the rulers advocating culture and suppressing martial arts, and ordinary people naturally attach importance to cultural development, so the entire Song Dynasty has a relatively strong cultural atmosphere.Coupled with the policy support of the rulers, the Northern Song Dynasty's cultural development environment is good.In simple terms, the implementation of the ruler's policies has changed the social atmosphere, and in a rich cultural atmosphere, the basic conditions for the revival of Confucianism have become better.

Once again, the Confucian scholars in the Song Dynasty actively devoted themselves to the practice of Confucianism revival ${ }^{[3]}$.The well-known Song writers such as Fan Zhongyan, Wang Anshi, and Ouyang Xiu are all active practitioners of the Confucian renaissance.Because these people had a very high status in the society at that time, the Confucian revival has further developed under the impetus of these people's practice.

Finally, the popularization of the imperial examination system and the advocacy of rulers. From the essence of Confucianism, the core of its ideology has a positive effect on the establishment of social order, and the use of Confucianism for social management will have more prominent management results. Therefore, in order to change the social outlook since the Five Dynasties, the Northern Song Dynasty actively promoted the application of Confucianism in social management, which laid a good social foundation for the rise of Confucianism. At the same time, the imperial examination system in the Song Dynasty was constantly improved, and the important content of the imperial examination was the Confucian classics. With the popularization of the imperial examination, social awareness of Confucianism deepened, which also contributed to the revival of Confucianism.

\section{2 performance}

The renaissance of Confucianism in the Song Dynasty brought new development and progress to Confucianism. In terms of specific performance, it is mainly reflected in the new theory and representative figures.

\subsubsection{Two cheng}

The so-called Er Cheng specifically refers to the brothers Cheng Hao and Cheng Yi, who are characters who cannot be ignored in the Confucian renaissance in the Song Dynasty. The two of them put forward a theory that "the knowledge of everything is the only thing, and all things are just the heavenly principle, and the heavenly principle is the origin of everything". This theory has influenced the development of Confucianism in later generations. 


\subsection{2 $\mathrm{Zhu} \mathrm{Xi}{ }^{[4]}$}

Zhu $\mathrm{Xi}$ can be said to be a landmark figure in the development of Confucianism. He is the most representative figure in the renaissance of Confucianism in the Song Dynasty.Judging from the specific influence of Zhu Xi, with the formation of Zhu Xi's Neo-Confucianism as a symbol, the development of Confucianism in the Song Dynasty has tended to be complete, and the goal of Confucianism revival is finally completed.From the middle of the Southern Song Dynasty, Zhu Xi's position in Confucianism continued to rise, and his influence continued to expand. Eventually, he occupied a dominant position in the ideological and academic circles, and rose to become an official ideology, affecting Chinese society for hundreds of years,play a decisive role in the shaping of national spirit and the formation of values. Play a decisive role in the shaping of national spirit and the formation of values.

\section{3 impact}

The influence of the Northern Song Confucianism renaissance is huge. From a practical analysis, its specific influence can be summarized in three aspects:1) Influence on Confucianism itself.From the pre-Qin to the Ming and Qing Dynasties, the development of Confucianism can be traced to the same origin., but in different eras, different contents have been integrated into the Confucianism, so the development trend and direction of Confucianism have changed.The revival of Confucianism in the Song Dynasty formed Confucianism that had a profound influence on later generations, and Confucianism also influenced the development content and direction of Confucianism in the Ming and Qing Dynasties.2) The impact on social atmosphere. The revival of Confucianism makes the atmosphere of social Confucianism more intense, which provides a very good environment for the development and inheritance of Confucianism.Throughout the successive reigns and dynasties, the elegant culture of the Song people is significantly related to the revival of Confucianism.3) Influence on later generations' rule and society.Although the Confucian Renaissance in the Song Dynasty was said to be the development of Confucianism, it was infiltrated with more content that was not favorable to social development.In the middle and late Ming Dynasty, the development of Confucianism was on the road to solidification, which caused significant problems in society and rule under the influence of Confucianism.Later, the content opposed by the New Culture Movement in China was mostly dross in the Confucian system.

\section{Discussion on the Phenomenon of Women's Ceremony in Song}

Under the background of Confucianism revival, it is very common for women in the Song Dynasty to worship Buddha. Analyzing and discussing the specific situation of women in the Song Dynasty praying to Buddha, this has a more significant role in understanding the life status and ideological dynamics of women in the Song Dynasty.

\subsection{A survey of Women's Worship to Buddha in Song Dynasty}

A summary analysis of the literature in the Song Dynasty can reveal the specific situation of women worshipping in the Song Dynasty.As far as the data shows, there are two main points in the Song Dynasty women's worship to Buddha.

The first is the universality of worship to Buddha.The so-called universal worship of Buddha specifically refers to the widespread behavior of women worshipping in the Song Dynasty.According to the data, the Song women praying to Buddha cover all ranks and classes:1) Worship to Buddha by upper middle class women.As far as the worship of the middle- and upper-class women in the Song Dynasty was concerned, their behavior was generally recorded in the epitaph $^{[5]}$.As far as the current data research is concerned, an important document that analyzes the worship behavior of middle-to-upper women in the Song Dynasty is «Compilation of Historical Materials on Stone Carvings of Past Dynasties》,According to the data, the epitaph clearly records that the tomb owner or the woman related to the tomb owner provided 234 people to Buddha worship, and the proportion was $24.6 \%$. This data has been significantly improved compared with the Tang Dynasty, which shows that Buddhism is widely popular among women in the Song Dynasty. As far as the middle and upper class women in the epitaphs are concerned, they mainly include the women of the royal family, the clan women, and the women of the bureaucrats.2) The lower girls pray to the Buddha.In the literature, there are not many records about the worship of lower women to Buddha, but from the perspective of the scene of the temple scene and the liveliness of the Buddhist puja, the lower women will not be absent.In addition, there are related records 
in some note novels, these records show that the lower-level women worship the Buddha universally.

The second is that women have various ways of worshiping Buddha.From the analysis of the available data, the content and methods of women's worship to Buddha are diverse.In terms of specific ritual behaviors and venues, women worshiping Buddha can be divided into two categories:1) Ritual Buddha within the house.Judging from the prayers to the Buddha in the women's house, there are many types, mainly divided into the following types:the first is vegetarianism. There are five precepts in the Buddhist family, one of which is to abstain from eating and drinking, so the woman who prays to the Buddha will express her attitude towards the Buddha by eating vegetarian food.The second is chanting sutras and chanting Buddha. Scriptures are Buddhist classics. Reading Scriptures is of great significance for understanding Buddhism, and at the same time being able to express their piety, so women always recite Scriptures at home.2) Saying Buddha outside the house. Praying to the Buddha outside the house refers specifically to women going out of the house to engage in worshiping the Buddha.Based on the summary of specific activities, there are mainly the following types:the first is the worship of the gods of the temple, which specifically refers to women worshipping the Buddha in the temple.Generally speaking, women worship Buddha prepare tribute and incense.The second type is the Buddhist Dharma, that is to participate in more important Buddhist or Dharma meetings. There are several important Buddhist priests, such as the Bath Buddha Club and the Bon Orchid Club, etc. Generally, in such activities, women who pray to the Buddha will participate as they do.

\subsection{Social attention to women's worship to Buddha}

It is a very common phenomenon for women to pray to Buddha in the Song Dynasty. It can be said that the worship of the Buddha has been integrated into the women's life.As far as the phenomenon of women's worship to Buddha is concerned, the Song Dynasty society showed two attitudes towards it, namely, advocating advocating and opposing criticism. The occurrence of this situation is mainly due to the specific analysis of women's worship to Buddha from the perspective of Confucianism.

As far as praise and advocacy is concerned, the reason why praise and advocacy promote women to worship is mainly based on the following views:1) Prayer to Buddha has a positive effect on self-cultivation.As far as the summary of the data is concerned, there are two types of praise for Lifo women, The first is indifference, and the second is positive.The so-called indifferent inaction also refers to a calm attitude in dealing with people, and has obvious tolerance for changes in the environment and circumstances, even if it is death, it is relatively indifferent;And the positive and effective is mainly manifested in the aspect of benevolence and charity.Prayer to Buddha improves a woman's selfcultivation, and her own behavior is more in line with the Confucian basic idea of "remain indifferent whether favoured or humiliated".2) Prayer to Buddha has a positive effect on family harmony.Praying to Buddha can calm down your mind and reduce your morale, so that problems such as family quarrels will occur less often.Harmony of family homes has a positive effect on social stability.3) Prayer to Buddha has significant value for children's education. In general, society promotes women to worship Buddha because of its many benefits.

In terms of opposing criticism, the reason why women are criticized for worshipping Buddha is mainly because of the following aspects:1) Praying to Buddha is "appear in public"and women should do housework and avoid showing up outside.Worship to Buddha Because of the need to attend some Buddhist ceremonies, and sometimes to burn incense to worship in temples, the chance of appearing has increased significantly.Those who oppose women's worship to Buddha believe that their behavior is counterintuitive.2) To perform well the duties of women, Confucianism believes that the responsibility of women is to perform housework and to teach children, so their behaviors should focus on "home". Praying to Buddha is an act that has nothing to do with home. It is a waste of time and a certain amount of money. This is a delay to your own work.

In general, there is a clear contradiction in the society's views on women's ritual and Buddha behaviors. It is clear that this contradiction is of great significance for the correct analysis and recognition of women's ritual and Buddha behaviors.

\section{Conclusion}

In summary, the revival of Confucianism in the Song Dynasty had a significant impact on the development of 
Confucianism in later generations.Moreover, in the context of the renaissance of Confucianism, the phenomenon of women ritual Buddha is more common.There are differences in the realization of Confucian cognition of women worshiping Buddha, and the analysis of specific issues from different angles has outstanding practical value for the realization of Confucian cognition.

\section{references}

1. Xu Shuang. Women Li Buddha in the Confucian Renaissance in Song Dynasty [J]. Shizhi Academic Journal, 2019(3).

2. Gao Huixia, Yang Zezhu, Xiang Shiling. The Yangtze River Academic Literature Series·Song Dynasty Classics Philosophy Research: Confucianism Revival Volume[M]// The Yangtze River Academic Literature Series·Song Dynasty Classics Philosophy Research:Confucianism Revival Volume. Shanghai Science and Technology Literature Press, 2015.

3. Zhou Jie. An Analysis of the Confucian Revival Trend of Thought and the Creation of Xueji in the Northern Song Dynasty[J]. All walks of life, 2019(2):171-173.

4. Mao Pengcheng, Jiang Chunjiao. The Northern Song Dynasty Jinshi Poems and Fus and the Confucianism Revival[J]. Chinese Examination, 2018, 320(12): 71-76+81.

5. Renxi. A Summary of the Symposium on "Modern Transformation of Confucianism and Construction of Confucian Free Concept"[J].Guan Zi Academic Journal,2018,126(04):121-124. 